\title{
ON PHOTOGRAPHY IN LATE CAPITALISM: REFLECTIONS ON THE VICISSITUDES OF THE IMAGE FROM A FILIPINO PERSPECTIVE
}

\author{
E. San Juan, Jr. \\ Harry Ransom Center, University of Texas, Austin \\ philcsc@gmail.com
}

\begin{abstract}
Ever since its invention at the outset of industrial capitalism in 19th-century Europe, photography has been used in the service of profit/capital accumulation worldwide. Appearances acquired saleable reality or marketable truth-value. The use of imagery and various forms of reproduction (film, advertising in TV, Internet, malls) subtends the dynamics of exchange-value in fixating human desires attuned to manipulated appearances. Can the critical analysis of photographic images help elucidate the mechanisms of ideology and the illusion industry for an emancipatory project? This essay seeks to enable a hypothetical inquiry into the magic of images with reference to the Philippine milieu, designed to be hopefully heuristic and propaedeutic.
\end{abstract}

\section{Keywords}

photography, capitalism, images, commodity, appearance, imperialism, colonialism

\section{About the Author}

E. San Juan, Jr., Emeritus Professor of English, Comparative Literature and Ethnic Studies, was recently a fellow of the Harry Ransom Center, University of Texas; and of the W.E.B. Du Bois Institute, Harvard University. He was previously visiting professor of American Studies at Leuven University, Belgium; and also at Tsing-hua University, Taiwan. His recent books are In the Wake of Terror (Lexington), Critique and Social Transformation (Mellen), US Imperialism and Revolution in the Philippines (Palgrave), and Critical Interventions (Lambert). 
"The camera makes reality atomic, manageable and opaque....denies interconnectness, continuity, but confers on each moment the character of a mystery." - Susan Sontag

\section{A Snapshot in the Shattered Mirror}

Photography, together with the technology of image-reproduction by the camera and its evolution, has accompanied the beginning of industrial capitalism in the 19th century. Reflecting on the history of this medium in 1931, Walter Benjamin remarked that only photography can reveal to anyone "the optical unconscious" analogous to the compulsive unconscious disclosed by psychoanalysis. He added that Atget is the photographer who liberated the object from "aura," the theological mystifying halo that surrounded portraits/landscapes taken by commercial uses of the camera. Each of Atget's snapshots can be likened to a crime scene with every passerby a criminal. Benjamin rhetorically queried: "Is it not the photographer's job (as heir to augurs and haruspices) to reveal guilt in his images and finger the culprit?" (192).

Detective inquiry, adjudication of responsibility, and ideological legitimization are not too far apart. Commenting on Susan Sontag's On Photography (in his book About Looking), John Berger contends that film and photography have been used by capitalism/imperialism to legitimize things as they are, the status quo, as immediately valid and truthful. A picture is equivalent to a thousand words; you see the reality as it is. "And that's the way the world is," as so many TV reporters/ commentators repeat everyday. Is the world you live in really what you see in snapshots? Is seeing believing?

Our daily lives sometimes may refute the immediate testimony of photographs and filmic images. How do we ascertain the true and the false, appearance and realitysuch are the old-fashioned puzzles of ontology and morality. However, the "false consciousness" that prevails in bourgeois and neocolonized societies has transformed daily lives into simulacra or mimicry of the painful experiences of ordinary people. We have artificial needs and desires cultivated by mass media, advertising, publicity. Our dreams and hopes are often constructed on TV images, film scenarios, and photos in megamalls, Facebook, and other cyberspace locations.

Photos offer only appearances deprived of their social and political contexts. The images found in snapshots are torn away from their place in the narrative of daily life. They are frozen, fetishized, given the aura that makes them appear sacred, immutable, normal. That has been the function of photography and film employed in industrial capitalistic societies and their colonial/neocolonized dependencies. You don't need to read Baudrillard, Slavoj Žižek, or Badiou, to apprehend this actuality happening in quotidian experience.

How to subvert this usage that promotes exploitation, destruction of the environment, permanent wastage of life and nature? Berger suggests that 
we incorporate photos into social and political memory. Following Brecht's instructions for the epic theater, Berger urges that we situate the photograph so that it "acquires something of the surprising conclusiveness of that which was and is." In other words, the radical artist in film and photography should show "the flow of events [...], permitting the spectator /To experience this Now on many levels, coming from Previously and /Merging into Afterwards, also having much else Now /Alongside it" (For Brecht's pedagogical maxims applicable to camera work, see Willett and Jameson.) "Always historicize," Fredric Jameson once intoned. But who can do this today when you are surfing the Internet, YOUTUBE, and singing Whitney Houston's "I will always love you...." in McDonalds or PizzaHut diners, or in voguish Starbucks in Quezon City or Makati?

I offer one photo that viewers should situate in narrated time. It can be a text for experimental metacommentary, as Jameson advised. This narrated time, to quote Berger again, "becomes historic time when it is assumed by social memory and social action." (61) This is a tall order, but I offer some cues and hints so that "a radial system" (antithetical to the auratified time of shopping, routine bureaucratic work, the tautology of spectator sports and watching the Justice Corona impeachment farce, Pacquiao's antics, barkada hijinks, TV trivia, etc. [Philippine current events circa 2012) can be constructed around the image so thatin Berger's words"it may be seen in terms which are simultaneously personal, political, economic, dramatic, everyday and historic." Connect the instant with what came before, and what will come after. Speculate, if possible: Where will this blind prisoner/ex-prisoner go? What will happen to him? How about the others surrounding him before, now, and after?

Walter Benjamin, the theoreticians of ostranenie (to estrange) and surrealist poetics, Russian futurists, among others, have proposed the maxim of "making strange" what we have been socialized to accept as normal, fixed, customary, acceptable, and fated. Deconstruct the illusion, destroy the mirage and hallucinations of quotidian life. This resembles the defamiliarization technique theorized by William Wordsworth and Samuel Taylor Coleridge when they cooperated in producing Lyrical Ballads (1798).

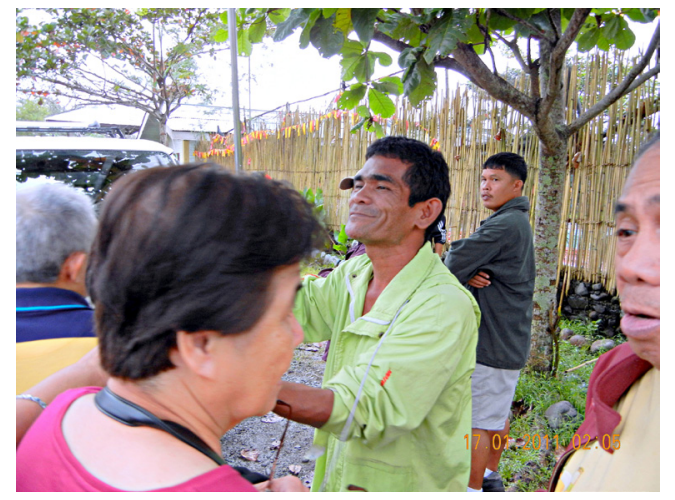

Here is a blind man at the center of the photo, taken in 2011 at the Palawan model "penal colony," among FilipinoAmerican tourists who were following the usual itineraryfrom the crocodile farm of Puerto Princesa, to the faux utopia of Dos Palmas (where the Burnham couple and other tourists were

Fig. 1: A blind man at Puerto Princesa, Palawan in 2011 
kidnapped by the Abu Sayyaf a few years ago), and finally to the underground river and caverns off the Palawan coast. Among the blind, the one-eyed fellow is king. How about those with two eyes? If we follow him, where will he lead us to?

Meanwhile, do we see the Abu Sayyaf pirates around the corner? Or, the killing of environmentalists and other activists in Palawan itself? How exemplary was the penal colony established by the American colonial administration (next to the Culion Leper colony) and perpetuated up to now? This picture speaks volumes, perhaps, only if youthe viewer, spectator, Baudelaire's mon lecteur can supply the narrative context from which meaning and signification can emerge. What Charles Sanders Peirce called the "interpretant" in the triadic theory of signs (sign/semiotic object/interpretant) can only be conceivable if the mind-forged manacles can be exploded by a process of collective action. For the interpretant is not another paraphrase or gloss but a mode of conduct, principled action, deliberate project. Who can explode those manacles that William Blake denounced? As the old vernacular slogan urged us: "Makibaka, huwag matakot?" ("Dare to Struggle, never fear!")

\section{The Interpreter as Producer}

Can the Revolutionary Masses Seize the Mass-Media Means of Production and Reproduction?

We intervene at the conjuncture of this conversation with friends and kasamas. Beginning with the axiom that humans initially produced culture by inter alia mastering and inventing tools, by deploying extensions of the bodyupdated as McLuhan's thesis of "the medium is the message"can we assume that tools such as the camera and computers are neutral? Can photography be seized by the masses to subvert its function as a powerful instrument of the ruling class for suppression and mobilize it for counter-hegemonic ends?

In short, can we turn Facebook and the Internet as Mao's "gun-barrel" to destroy the organs of publicity, advertising, celebrity-fabrication, and deceitful mythmaking at the service of profit/capital? In a timely response to my previous note, Prof. Ruel Pepa of Trinity University of Asia posed a provocative challenge that the question of verisimilitude, of veracity, depends on who is asking and for what purpose.

It is then a question of means and ends. While current mass media (television, mass media, films, and the whole ideological state-apparatus that Althusser designated as instrumental in the capitalist State's interpellation of docile subjects) generally serves the $1 \%$, the predatory minority, Pepa suggests, we can capture media, or at least use parts of this apparatus, to advance the revolutionary goals of the 99\%--to echo the memorable and now epochal slogans of the worldwide OCCUPY movement. 
In short, we can seize the weapons of the master to turn them against the structures of domination and exploitation, the controlling institutions of the neocolonial order embedded in the Empire. Is it that easy? Of course, isn't this what the Calibans did, what the servants in Bunuel's film Viridiana did? Didn't the Propagandistasdel Pilar, Rizal, and the plebeian comrades of these ilustrados (Bonifacio, Jacinto, Mabini) use the colonizer's weapons to overthrow their rule? Didn't Marx use Hegel, Ricardo, Saint Simoun, Fourier, and the whole achievement of bourgeois civilization--even the slave-enabled achievements of Epicurus and Stoic humanists--to expose its illusion, its fragility and its transitoriness? Mao read Dewey and Western classics; Ho Chi Minh even quoted the words of Locke paraphrased in the American Declaration of Independence. Indeed, such is the complex dialectical process of liberation in actual history in which opposites unite only to separate in revolutionary collisions and fusions.

Indeed, the cunning of reason demands astute coaxing and management. Materialist dialectics means not only preserving parts of the old but also negating the larger substance of idealist thinking. In effect, materialist dialectics implies a transformation not only of the weapon but the modalities of its use. In the case of wresting control of the media, including the means of producing powerful critiques and oppositional interpretations that can unbalance the bourgeois control of the media, one confronts a more complex problem not resolvable by formulas and precedents.

Previous researches by Herbert Schiller, Michael Parenti, as well as by Roberrt McChesney, Ellen Meiksins Wood and John Bellamy Foster (see their Capitalism and the Information Age, 1998), among others, have shown how total and massive is the capitalist control of the globalized media, even in the face of challenges from anti-imperialist quarters (from Hugo Chavez, WikiLeaks, Anonymous, and other alternative projects). Not to speak of the almost totalbut not quitezombification of minds and bodies of consuming masses everywhere addicted to malling, shopping, potlatchinunnecessary expenditures of the body and spirit now and at the hour, in the political economy of narcissistic desire. One speculates whether Kingdom Come has finally arrived with the neoliberal utopia of post-9/11 drones, NSA worldwide surveillance, and vacuous derivatives, courtesy of Wall Street/Pentagon "humanitarian" interventions.

One of the sharpest demystifiers of the distraction/culture industry is the German Marxist philosopher W.F. Haug. In his magisterial study of capitalist advertising / propaganda which he theorized as "commodity aesthetics," Haug argues that the need for collective praxis is displaced; in detective films, psychothrillers and disaster films, pseudo-significant collective actions are purveyed to canalize widespread frustration, anger, and anxiety: "Isolated coexistence, persistent fear and competitiveness, and disguised class conflict, are sanitized by illusions into basic friend-or-foe relationships; in dealing with the enemy destruction meets with destruction, while the 'goodies' cooperate, mixed with the occasional eroticization 
of solidarity and comradeship" (121). In the case of images broadcast by media, Haug contends that

appearance always promises more, much more, than it can ever deliver. . This deceptive illusion is devised here from the standpoint of owning exchangevalue. .. In these images, people are continually shown the unfulfilled aspects of their existence. The illusion ingratiates itself, promising satisfaction: it reads desires in one's eyes, and brings them to the surface of the commodity. (51-52)

And these commodities, in various shapes and constellations, give people a sense of meaningfulness, illusions of fulfillment and solidarity/fellowship, intimacy," thus cultivating greed and laziness equally. This is the secret of the power of money/ profit/capital accumulation in global finance capitalism: ersatz self-fulfillment, simulated togetherness, vicarious imaginary belonging in one harmonious society, equal participation in one caring and compassionate world.

Capitalist hegemony, of course, succeeds because it allows the dominated/ subjugated to be part of its articulation. Or at least the majority are led to believe that its interests are being promoted by its accepting its position in the structure; hence, it allows minority voices to be heard, to participate under certain conditions, etc. Such is the much touted consensus of so-called democracies and their legitimacy warrant.

We can even allow consumer goods/commodities to perform symbolic roles and functions, as Mary Douglas has argued in her influential discourse on methodological individualism for neoliberals, The World of Goods. Douglas is the poor man's Anglo-Saxon version of the postmodernist postmarxism of Baudrillard, Deleuze and Guattari. She reminds us again that commodities not only satisfy physical and psychic needs, they also serve as information, as organic parts of a communication system in any social formation. Symbolic capital, in Bourdieu's terms. Granted, but this does not abolish the dichotomy between use-value and exchange-value. In fact, as W.F. Haug, Pierre Bourdieu, Guy Debord and others have shown, commodity-aesthetics depends precisely on the way "use-value" is inscribed in the system of symbolic exchange. No use value, no exchange. This is the axiom ignored or dismissed by the current scholars of neoliberal postcoloniality, transnationalism, and cosmopolitan globalism.

This is perhaps why Jacques Rancière can argue that it is the aesthetic regime of visibility that subverts the bourgeois hierarchy of values, whereby the ordinary or anonymous becomes "beautiful as the trace of the true." But the question is (to follow Rancière in The Politics of Aesthetics) how can commodities be wrested from their trivial appearances and "beautified," so to speak, or "made into phantasmagoric objects in order to be interpreted as the expression of society's contradictions"? Rancière is trying to apply the surrealist formula of estrangement, 
Brecht's Verfremdung-effekt, to all sphere of global capitalism. But for what purpose, what consequence? In short, does it serve the goal of a worldwide transformative, sustainable anticapitalist program?

In late capitalism, everything seems not only contradictory but thoroughly perverted and transmogrified by the cash/market logic of equivalence. John Berger, Stuart Ewen (in his All Consuming Images), Victor Burgin, Naomi Klein, Peter Osborne, and others have shown the insidious complicity of image-producing art /mechanisms with the logic of profit-making and capital accumulation. In short, photography (as well as film, theater, literature and other discursive practices) have been utilized to advance exploitation and oppression for a long time since its instrumentalization in 1855, at the Paris Exposition. And so what else is new?

In effect, Rancière argues against Benjamin's thesis that the modernist age of mechanical reproduction has finally destroyed the aura of bourgeois/aristocratic value in goods. Rancière disagrees. He believes that the loss of aura has not demystified commodities and has not converted their iconic status to an indexical realist one. What is needed, according to Rancière, is to restore the aesthetic dimension of worldly goods to their normalized, positivized appearances. In short, we need to defamiliarize commodities, make them strange or phantasmagoric. We need to enchant again the disenchanted world of the marketized urban world, abolish the material basis of labor alienation in the unequal distribution of power and resources, and democratize the whole system radically and thoroughly.

Demystification is then the urgent agenda. While Stieglitz, Strand or Evans appropriated the commonplace and ordinary into affective, significant photographic discourse, what is needed todayRancière arguesis to make the commonplace, the ordinary and anonymous peculiar, even perverse, so as to stand out from the mesmerizing banality of everyday commercialized /commodified life. In short, we have to break the aura of normal business routine, the bureaucratic modes of consumer society, in order to rescue fragments of humanity and restore the dignity of the natural world. But how do we do this?

Shock tactics seem called for, the sudden blast of illumination conjured by Rimbaud and the visionaries of surrealist avant-gardism. Or the thundering appeal of the Communist Manifesto and its international reverberations.. For the moment, however, let us engage in a thought-experiment, or visual hypothesizing. Following Edward Weston's advice to think photographically. But how do we do this in the case of these photographs of beggars in the "land of the morning sun," Jose Rizal's "pearl of the Orient Seas," when consciousness itself, including our dreams and fantasies, have all been virtually polluted by the individualist ethos and neoliberal habitus we already take for granted as the immutable norm? 

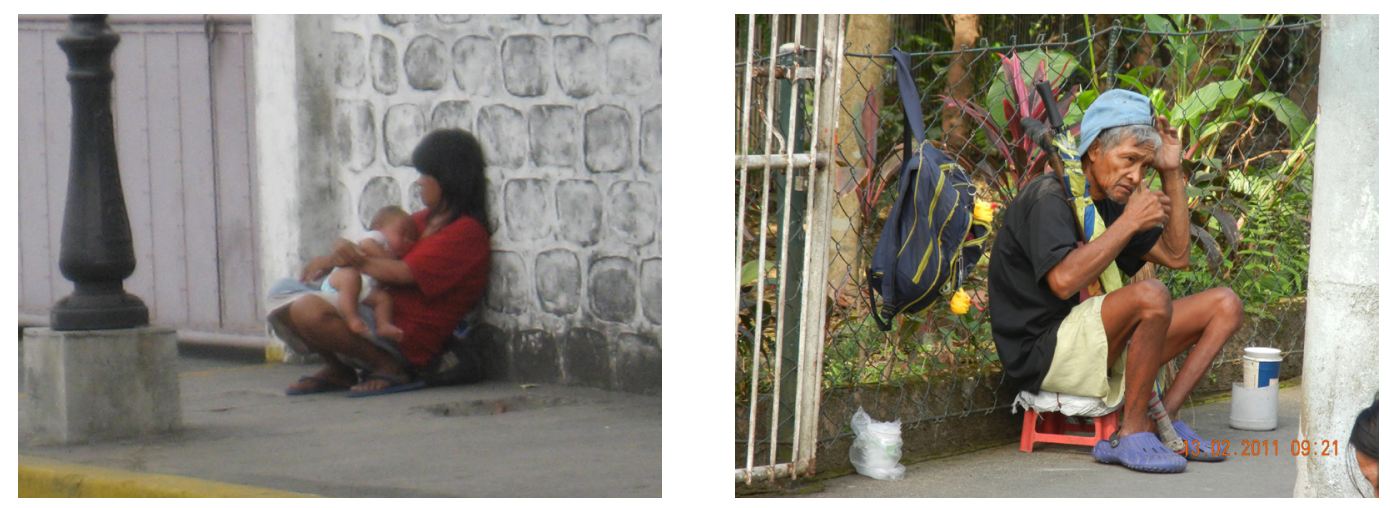

Fig. 2 \& 3: Beggars in metropolitan Philippines

To be sure, beggars will never unite--unless they organize and reflect on their position in the whole system, as well as discover solidarity with the rest of the "wretched of the earth." Meanwhile, do we need the terrorist Abu Sayyaf to revisit Dos Palmas islands, perhaps even the dangerous, contested Spratleys where the US (via the neocolonial local oligarchs), China, Vietnam and Taiwan are today confronting each other's military might? Of course, they are already there, propped up by the local warlords, functioning as the raison d'etre for full-spectrum US dominance.

\section{On the Possible Agitational/Pedagogica Use of Images}

At this conjuncture, one may hazard the question: Is it the case that of all human inventions, the photograph is the most enigmatic and menacing one today?

We are informed by the French critic Roland Barthes, in his seminal 1961 essay, "The Photographic Message," that the photograph is a message without a code. All signs produce meaning derived from their position in a system of differences, following Saussure. And ultimately the signifieds of signifiers (words, visual motifs, musical notes) become intelligible within a code of social conventions and cultural beliefs. All art depends on the system of connotationsstyle, period rhetoric, traditional symbols, stereotypesfor their sounds/shapes to signify. But the photograph is unique because it is self-sufficient in its "analogical plenitude." Does this mean it is a perfect copy of the "real" and needs no code to unlock it?

Almost everyone values photographs as veritable copies of what is real, what appears. Otherwise, we won't hire photographers to immortalize our weddings, birthday celebrations, feasts, etc. Look, it's really Nanay and Tatay, Tito and Tita! Even our local movie stars turn on the laptop cameras to record and broadcast their bedroom antics for their fans, and for the millions of YOUTUBE addicts in McLuhan's globalized village. 
The famous French photographer Henri Cartier-Bresson is regularly praised as someone who captured with "perfect transparency the character of what he saw. His Americans look intensely American. His Chinese look impeccably Chinese." Astounding or trivial? How did Mr. Verlyn Klinkenborg (writing for The New York Times, 6 August 2004) arrive at this judgment? Can one still disavow our social mediatization in front of our cellphone cameras, minipads, and Internet linkages? Everyone seems connected, one way or the other; we belong to "the family of humans," so no one need be alone and suffer the proverbial trauma of postmodern mourning and melancholia. Solitude has become a luxury, affordable only to those who can retreat to their villas in some island or retreat in the mountains of Bontoc, surrounded by your security entourage.

The camera reproduces or copies some object out there, to be sure. The photo is not an emanation of our psyche. Barthes explains that the photograph is a message without a code because it is the perfect analogon of reality. Viewed from the semiotics of Charles S. Peirce, the photograph functions as an icon that resembles what the film registers; but it also acts as an index which points to something outside the minds of viewers (Short). Note here that this double function is the key to its expressive efficacy. For Barthes, what the image denotes acquires primacy. Nonetheless, because the denoted reality (when the photograph is used in the mass media of communication) acquires a repertoire of connotations that give it historical and social meanings, the photograph becomes transparent. It thus becomes legible and readable.

Later on, in Camera Lucida (1980), Barthes the post-structuralist indicts the parasitic exploitation of images by consumerist bourgeois society: first, by transforming the photograph into autonomous art which in turn is exchanged as commodities in the market; and second, by banalizing it in advertising, pornography, celebrity fetishism, official propaganda, etc. What is to be done? Barthes can only suggest that either we subject the spectacle provided by the camera to "the civilized code of perfect illusions," domesticating it within the academic realm of photography as art; or "to confront in it the wakening of intractable reality."

The latter is perhaps the more worthwhile choice we should try to make when examining the photographs I took of these dancers from the villages surrounding Loboc River in Bohol this March 2012. It is a snapshot of a mass gathering of seemingly anonymous folks, one group made up of villagers who all know each other, the Otherness of tourists gripped by tourist ennui and the routine boredom induced by commodified spectacles and manufactured exotic distractions. 


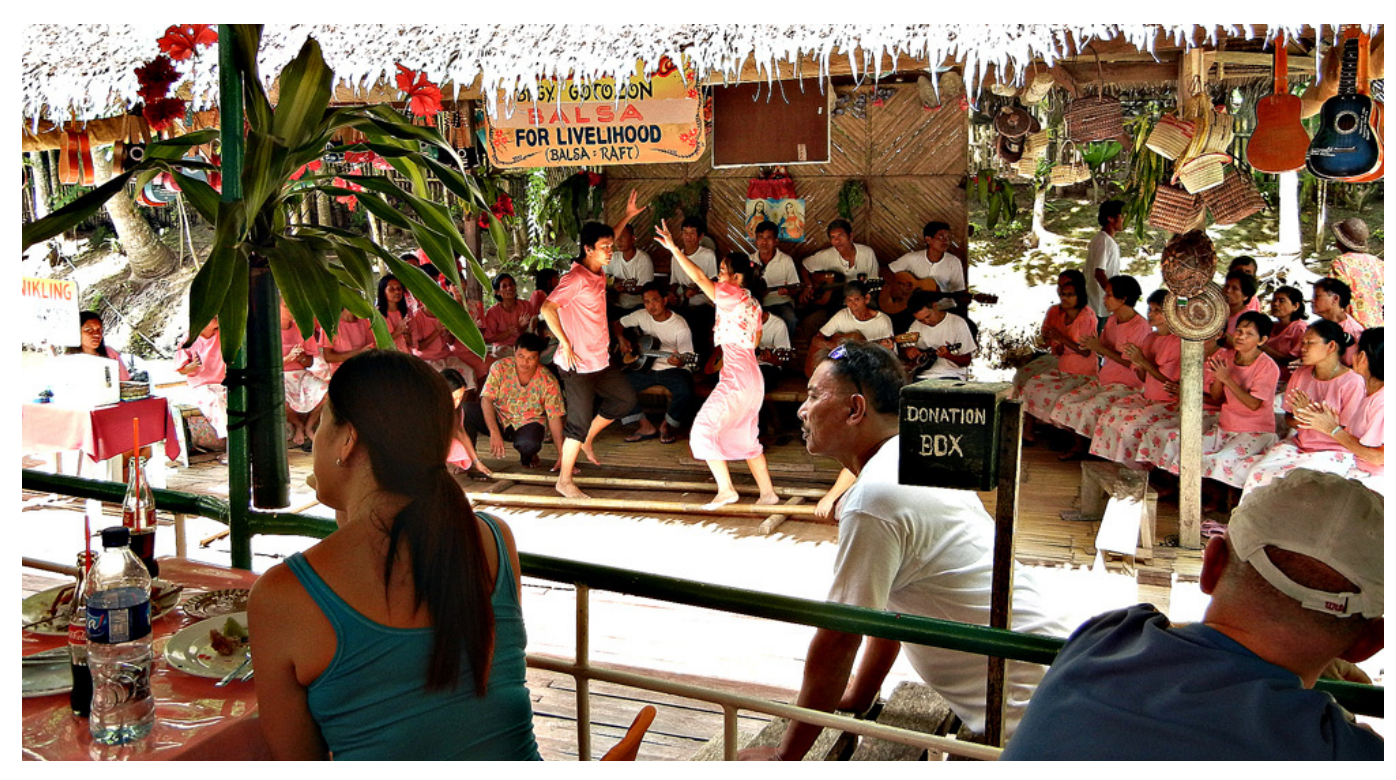

Fig. 4: Local dancers at Loboc River, Bohol

The photographer maneuvers on board one of those commercial boats for tourists. At certain stops along the way, platforms were built for the local villagers to stage native dances to relieve the monotony of the landscape. Such performances are paid by the companies controlling the tourist trade. The labor of the villagers is exhibited ostensibly as part of the livelihood programs of the barangay or local government. What kind of livelihood is shown here? What is the spectacle and who are the spectators?

We gaze then at these ordinary natives who have been organized to perform for tourists riding the boats going up and down the river, remunerated by the businesses operating the cruises, restaurants, bazaars, etc. We are compelled to wonder, from hindsight: are these Filipinos impeccably Filipinos? This is to echo Mr. Klinkenborg's anxious quest for authenticity. Perhaps I have just provided something of a code to the messages one can extract from these images. Or at least a hint or cue as to how the camera intervened to register what purports to be "real," what claims to be the appearances. One can of course prefer to look at the falls at the end of the river, or resign one's mind to other sideline attractions/distractions.

Assaying the history of photography in the thirties (as noted earlier), Walter Benjamin emphasized its constructivist role based on experiment and instruction, ascertaining what has been erased or subsumed by what Debord called "the society of the spectacle": "Is it not the photographer's job (as heir to augurs and haruspices) to reveal guilt in his images and finger the culprit?" (192; see also Osborne, Politics, 136-38). Apropos of Benjamin's insight that contrary to the 
popular doxa, photography can reveal the "optical unconscious," the reality behind appearances, Rosalind Krauss speculates that the specular "unconscious" can be constructed by the artist in the visual field. It can be actualized in the photograph as "a projection of the way that human vision can be thought to be less than a master of all it surveys" (89) That is, the photo can be in conflict with the belief or sentiment that vision can capture the most valuable or significant elements of the world, if not the essential core of what appears. That hubris is disintegrated by the discrepancies and contradictions we discover between the photograph and the context of its making.

So then the challenge is how to read or interpret these photographs so that we can derive some value from looking at them. Either we civilize these images into safe, exotic appearances of charming natives, or stir up the explosive ingredients discoverable in the gestures, smiles and seductive faces of our performers. Or we can just nod ang give thanks for our daily bread of images, knowing that there is a time for this and a time for that, until time runs out, memory and history too, and the planet rejoins the dust of the infinite galaxies.

But look at the photo again. Notice, however, that there is another messenger to which the spectators turn their gazes, perhaps the materials for a Molotov cocktail for the Establishment censors, the gatekeepers of our everyday psyches. Perhaps we need to turn at ourselves and reflect on how we are complicit in these spectacles, producing and reproducing the hierarchies of power and the inequalities of symbolic capital in our everyday lives. After all, we are Filipinos subjected to the gaze of the imperial camera everyday. De te fabula.

In this post-9/11 epoch, specifically the age of digital photographs of Abu Ghraib/ Guantanamo prison cells, Google World Maps and Aerial Viewing, of total surveillance by the U.S. State apparatuses revealed by Bradley Manning and Edward Snowden which dwarfs the Panopticon syndrome famously analyzed by Michel Foucault, we face a new problem: digitalization. The most acute commentator of this contemporary phenomenon is the British critic-philosopher Peter Osborne. He remarks about the proliferating multiplication of visualizations, how digital networks (via computerized instrumentalities of all sorts and conceivable technologies of transmission) have radically altered social space, including art space. The photographic image of the old camera has been decoupled from its indexical ground, thus destroying the basis of art as a form of self-conscious illusion.

Osborne urges us to meditate on these questions: "Might it not be the growing self-consciousness of the potentially illusory character of the photographic image, subsequent to its digitalization, that makes it the form of image most appropriate to art as self-conscious illusion? And is there not thus a strange convergence here between the digital image and the commodity form?" (Anywhere 129). The ontological peculiarity or self-sufficiency of digitalized data makes it a variant of "the essentially theological character of the traditionally chemical-based photographic image itself." (Anywhere 129) Is the digital image then similar to 
a Byzantine icon, a visible copy of an invisible God? Osborne remarks that the digitalized image exhibits "a de-temporalization of the theological structure of the photograph," giving way to "the multiplication of varieties of forms of visualization made possible by that rupture, within the parameters of what are still, essentially, processes of replication" (Anywhere 129-30). We are back to the world of fantasies, of Scheherazade and mesmerizing scenarios of the pasyon/senakulo, or alternatively utopian projections of nostalgic Gardens of Eden and the enchanting ruins of the mythical Golden Age.

What's at stake? The challenge for us now is to critically analyze and evaluate, through modes of Peircean fallibilistic inquiry, these myriad modes of visualization that function not only as "imaginary resolution of lived contradictions" (pace Althusser) but lived experiences of joyful fulfillment of communal desires. In short, how can we overthrow the dominance of exchange-value (money/profit) without sacrificing use-value, including the basis of this fatally-linked binary pair? The choice ultimately for Filipinos and citizens of this planet may be a wager on who wins in the end: the terror of U.S. imperial barbarism or plural experiments in democratic socialism? Persistent neocolonial misery for over a hundred million Filipinos around the planet or national-democratic liberation and true independence from predatory global corporate tyranny? Each one has to decide for herself in conjunction with those Others captured here in images. 


\section{Works Cited}

Barthes, Roland. Camera Lucida. Trans. Richard Howard. New York: Hill and Wang, 1980. Print.

---. Image Music Text. Trans. Stephen Heath. New York: Hill and Wang, 1977. Print.

Benjamin, Walter. One-Way Street and Other Writings. Trans. J. A. Underwood. London: Penguin, 2009. Print.

Berger, John. About Looking. New York: Pantheon, 1980. Print.

Burgin, Victor, ed. Thinking Photography. New York: Macmillan. Print.

Debord, Guy. Society of the Spectacle. Trans. Black and Red Editors. Detroit: Black and Red, 1977. Print.

Ewen, Stuart. All Consuming Images. New York: Basic, 1990. Print.

Haug, W. F. Critique of Commodity Aesthetics. Trans. Robert Bock. Minneapolis: U of Minnesota P, 1986. Print.

Jameson, Fredric. Brecht and Method. London: Verso, 1998. Print.

Krauss, Rosalind. The Optical Unconscious. Cambridge, MA: MIT Press, 1994. Print.

Osborne, Peter. Anywhere or Not At All: Philosophy of Contemporary Art. London: Verso, 2013. Print.

--. The Politics of Time: Modernity and Avant-Garde. London: Verso, 1995. Print.

Rancière, Jacques. The Politics of Aesthetics. Trans. Gabriel Rockhill. New York: Continuum, 2004. Print.

Short, T. J. Peirce's Theory of Signs. New York: Cambridge University Press, 2007. Print. Sontag, Susan. On Photography. New York: Penguin, 1977. Print.

Willett, John. The Theatre of Bertolt Brecht. New York: New Directions, 1968. Print. 